\title{
The Role of Peroxisome Proliferator-Activated Receptor $\beta / \delta$ on the Inflammatory Basis of Metabolic Disease
}

\author{
Teresa Coll, Emma Barroso, David Álvarez-Guardia, Lucía Serrano, Laia Salvadó, \\ Manuel Merlos, Xavier Palomer, and Manuel Vázquez-Carrera
}

Department of Pharmacology and Therapeutic Chemistry, CIBER de Diabetes y Enfermedades Metabólicas

Asociadas (CIBERDEM)-Instituto de Salud Carlos III and Institut de Biomedicina de la Universitat de Barcelona (IBUB), Faculty of Pharmacy, University of Barcelona, Diagonal 643, 08028 Barcelona, Spain

Correspondence should be addressed to Manuel Vázquez-Carrera, mvazquezcarrera@ub.edu

Received 20 May 2010; Accepted 28 June 2010

Academic Editor: Marcelo Napimoga

Copyright (C) 2010 Teresa Coll et al. This is an open access article distributed under the Creative Commons Attribution License, which permits unrestricted use, distribution, and reproduction in any medium, provided the original work is properly cited.

\begin{abstract}
The pathophysiology underlying several metabolic diseases, such as obesity, type 2 diabetes mellitus, and atherosclerosis, involves a state of chronic low-level inflammation. Evidence is now emerging that the nuclear receptor Peroxisome Proliferator-Activated Receptor (PPAR) $\beta / \delta$ ameliorates these pathologies partly through its anti-inflammatory effects. PPAR $\beta / \delta$ activation prevents the production of inflammatory cytokines by adipocytes, and it is involved in the acquisition of the anti-inflammatory phenotype of macrophages infiltrated in adipose tissue. Furthermore, PPAR $\beta / \delta$ ligands prevent fatty acid-induced inflammation in skeletal muscle cells, avoid the development of cardiac hypertrophy, and suppress macrophage-derived inflammation in atherosclerosis. These data are promising and suggest that $\operatorname{PPAR} \beta / \delta$ ligands may become a therapeutic option for preventing the inflammatory basis of metabolic diseases.
\end{abstract}

\section{Introduction}

Over the last decade, an abundance of evidence has shown a close link between a state of chronic low-level inflammation and metabolic dysfunction. In fact, excessive nutrition consumption or storage has the capacity to activate both inflammatory and metabolic signaling networks since they are linked and interdependent [1].

Peroxisome Proliferator-Activated Receptors (PPARs), which are members of the nuclear receptor family, have emerged as important regulators of metabolic and inflammatory signaling, particularly in the context of metabolic disease [2-4]. The ability of these receptors to connect metabolism and inflammation makes them interesting targets for the treatment of metabolic diseases, such as atherosclerosis and diabetes, through modulation of the inflammatory process. Here, we will focus on recent advances in our understanding of the role of one of these PPAR members, the $\operatorname{PPAR} \beta / \delta$, as an integrator of metabolic and inflammatory signaling networks.

\section{Peroxisome Proliferator-Activated Receptors (PPARs)}

PPARs are members of the nuclear receptor superfamily of ligand-activated transcription factors that regulate the expression of genes involved in fatty acid uptake and oxidation, lipid metabolism, and inflammation [2]. To be transcriptionally active, PPARs need to heterodimerize with the 9-cis retinoic acid receptor (RXR) (NR2B) (Figure 1). PPAR-RXR heterodimers bind to DNA-specific sequences called peroxisome proliferator-response elements (PPREs), which consist of an imperfect direct repeat of the consensus binding site for nuclear hormone receptors (AGGTCA), separated by one nucleotide (Direct Repeat 1, DR-1). These sequences have been characterized within the promoter regions of PPAR target genes. The binding occurs in such a way that PPAR is always oriented to the DNA's $5^{\prime}$-end, while RXR is oriented to the $3^{\prime}$-end. In the absence of a ligand, high-affinity complexes are formed between PPAR-RXR heterodimers and nuclear receptor corepressor proteins, 
(1) Transactivation

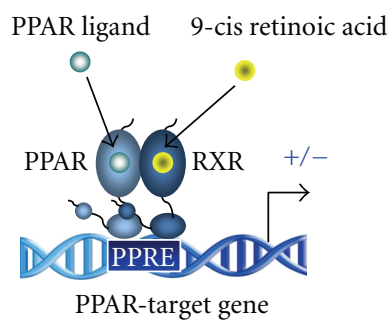

(2) Transrepression

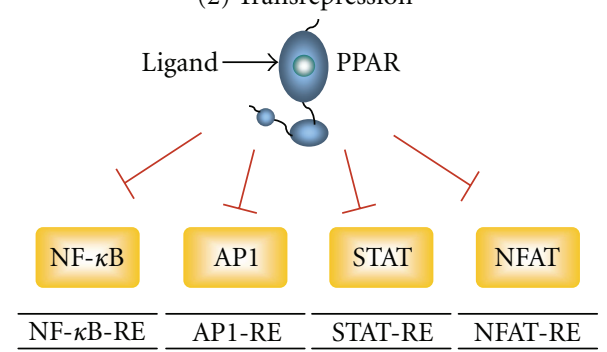

FIgURE 1: Molecular mechanisms of Peroxisome Proliferator-Activated Receptors (PPARs). PPARs are ligand-activated transcription factors that regulate gene expression through two mechanisms: transactivation and transrepression. In transactivation, PPAR-RXR heterodimers bind to DNA-specific sequences called peroxisome proliferator-response elements (PPREs), which are located in the promoter regions of genes involved in glucose and fatty acid metabolism. PPARs may also regulate gene expression through a DNA-independent mechanism called transrepression. Through this mechanism, PPARs inhibit the activity of several transcription factors such as Nuclear Factor- $\kappa \mathrm{B}$, which leads to anti-inflammatory effects. STAT denotes signal transducers and activators of transcription, IS-GFRE is the interferon-stimulated gene factor responsive element, and TRE is the TPA responsive element, where TPA is a phorbol ester.

which block transcriptional activation by sequestering the heterodimer from the promoter.

In a specific cellular context, the activity of PPARs that regulate the transcription of their target genes depends on many factors (relative expression of the PPARs, the promoter context of the target gene, the presence of coactivator, and corepressor proteins, etc.). Thus, the transcriptional activity of PPARs is modulated by coactivators and corepressors [5]. One of the best described PPAR coactivators is PPAR $\gamma$ coactivator $1 \alpha(\mathrm{PGC}-1 \alpha)$. Silencing mediator for retinoic and thyroid hormone receptor (SMRT) and the nuclear receptor corepressor are corepressors that interact with the PPARs in the absence of ligands [6]. Receptor-interacting protein 140 (RIP140), an important metabolic regulator, is another ligand-dependent corepressor which interacts with PPARs. Binding of the ligand to PPAR induces a conformational change resulting in dissociation of corepressor proteins, so that the PPAR-RXR heterodimer can then bind to PPREs. Moreover, once activated by the ligand, the heterodimer recruits coactivator proteins that promote the initiation of transcription [4]. As a result of these changes in transcriptional activity, binding of ligands to the receptor leads to changes in the expression level of mRNAs encoded by PPAR target genes.

Finally, PPAR activity is also regulated at the posttranscriptional level by phosphorylation, ubiquitinylation, and sumoylation (for a detailed review, see [5]).

However, the regulation of gene transcription by PPARs extends beyond their ability to transactivate specific target genes. PPARs also regulate gene expression independently of binding to PPREs. They cross-talk with other types of transcription factors and influence their function without binding to DNA, through a mechanism termed receptor-dependent trans-repression [7]. Most of the antiinflammatory effects of PPARs can probably be explained in this way $[8,9]$. Through this DNA-binding independent mechanism, PPARs suppress the activities of several transcription factors, including nuclear factor $\kappa \mathrm{B}$ (NF$\kappa \mathrm{B})$, activator protein 1 (AP-1), signal transducers and activators of transcription (STATs), and the nuclear factor of activated $\mathrm{T}$ cells (NFAT). There are three main transrepression mechanisms by which ligand-activated PPARRXR complexes negatively regulate the activities of other transcription factors. First, transrepression may result from competition for limited amounts of shared coactivators. Under conditions in which the levels of specific coactivators are rate-limiting, activation of PPAR may suppress the activity of other transcription factors that use the same coactivators $[10,11]$. In the second mechanism, activated PPAR-RXR heterodimers are believed to act through physical interaction with other transcription factors (e.g., AP-1, NF- $\kappa$ B, NFAT, or STATs). This association prevents the transcription factor from binding to its response element and thereby inhibits its ability to induce gene transcription [12]. The third transrepression mechanism relies on the ability of activated PPAR-RXR heterodimers to inhibit the phosphorylation and activation of certain members of the mitogen-activated protein kinase (MAPK) cascade [13], which prevents activation of downstream transcription factors.

The PPAR family consists of three members, PPAR $\alpha$ (NR1C1 according to the unified nomenclature system for the nuclear receptor superfamily), PPAR $\beta / \delta$ (NR1C2) and PPAR $\gamma$ (NR1C3) [14]. PPAR $\alpha$ was the first PPAR to be identified and is the molecular target of the fibrate hypolipidemic class of drugs. This PPAR isotype is expressed primarily in tissues that have a high level of fatty acid catabolism, such as liver, brown fat, kidney, heart, and skeletal muscle [15]. PPAR $\gamma$ has a restricted pattern of expression, mainly in white and brown adipose tissue and colon, and is also expressed in macrophages. Other tissues, such as skeletal muscle and heart, contain only limited amounts. PPAR $\beta / \delta$ is ubiquitously expressed and for this reason it was initially considered a "housekeeping gene" [16]. However, studies with knockout mice [17-19] and the development of specific and high-affinity ligands for this receptor have shown that $\operatorname{PPAR} \beta / \delta$ is a potential molecular target to prevent or treat several metabolic disorders. 
Natural ligands for the PPARs are believed to include native and modified polyunsaturated fatty acids and eicosanoids. Since the discovery of PPARs, a number of synthetic ligands for these receptors have been identified [20]. Thus, fibrates activate PPAR $\alpha$, whereas the antidiabetic drugs thiazolidinediones activate the $\gamma$ isotype $[21,22]$.

\section{PPAR $\beta / \delta$-Specific Features and Ligands}

The crystal structure of the ligand-binding domain of the $\operatorname{PPAR} \beta / \delta$ isotype, which was first cloned in Xenopus laevis [23], revealed an exceptionally large pocket of approximately $1300 \AA^{3}$. This pocket is similar to that of PPAR $\gamma$, but much larger than the pockets of other nuclear receptors $[24,25]$. This may partially explain the great variety of natural and synthetic ligands that bind to and activate this nuclear receptor. Saturated (14 to 18 carbons) and polyunsaturated (20 carbons in length) fatty acids have affinities for PPAR $\beta / \delta$ in the low micromolar range [25-28]. In addition, alltrans-retinoic acid (vitamin A) [29] and fatty acids derived from very low density lipoprotein (VLDL) [30] can activate $\operatorname{PPAR} \beta / \delta$. Finally, the number of experimental studies on the role of PPAR $\beta / \delta$ in cellular processes increased greatly as a result of the availability of several synthetic ligands (including GW501516, GW0742, and L-165041) that activate $\operatorname{PPAR} \beta / \delta$ at low concentrations both in vivo and in vitro and have high selectivity over other PPAR isotypes [31]. The $\mathrm{EC}_{50}$ for these compounds, which were assessed with recombinant human $\mathrm{PPAR} \beta / \delta$, were $1.0 \mathrm{nM}$ for GW0742, $1.1 \mathrm{nM}$ for GW501516, and $50 \mathrm{nM}$ for L-165041 [31, 32]. Recently, the first PPAR $\beta / \delta$ synthetic antagonist (GSK0660) has been identified [33].

\section{PPAR $\beta / \delta$, Inflammation, and Adipose Tissue}

The expansion of adipose tissue, mainly in the form of visceral obesity, may contribute to enhanced inflammation in this tissue through several processes. First, macrophages can infiltrate in adipose tissue, which contributes to the overproduction of inflammatory cytokines, such as tumor necrosis factor $\alpha$ (TNF- $\alpha$ ) and interleukin 6 (IL-6) [34-36]. Indeed, the infiltration of macrophages into adipose tissue correlates with the degree of insulin resistance [34]. Second, as visceral fat (which is very sensitive to lipolytic stimuli) increases, so does the rate of lipolysis. This leads to increased free fatty acid (FFA) mobilization and elevated levels of circulating FFA. Several studies have consistently demonstrated that elevations of plasma FFA produce insulin resistance in diabetic patients and in nondiabetic subjects [37-39]. Saturated FFA are potent activators of the Toll-like receptor- 4 (TLR4) [40] and recent evidence suggests that inflammatory processes induced by obesity and a high-fat diet cause systemic insulin resistance via a mechanism involving this receptor [41]. TLR-4 is expressed in virtually all human cells and binds a wide spectrum of exogenous and endogenous ligands, including bacterial lipopolysaccharide (LPS) [42]. In the presence of LPS, the TLR4 complex (including CD14 and an accessory protein, MD-2) recruits the adaptor protein, myeloid differentiation factor-88 (MyD88), which in turn recruits interleukin-1 receptor-associated kinase (IRAK). This leads to the activation of the proinflammatory transcription factor NF- $\kappa \mathrm{B}[43]$ and the subsequent enhanced expression of several inflammatory mediators (including IL-6 and monocyte chemoattractant protein-1 [MCP-1]). These observations indicate that saturated FFA derived from adipocytes and from high-fat diets activate TLR and the inflammatory pathway in adipocytes and macrophages, which contribute to the synthesis and production of cytokines such as TNF- $\alpha$ [44]. In addition, high-fat diets raise plasma LPS to a concentration that is high enough to increase body weight, fasting glycemia, and inflammation [45]. Furthermore, LPS receptor-deleted mice (CD14 mutants) are hypersensitive to insulin, and the development of insulin resistance, obesity, and diabetes in this animal model is delayed in response to a high-fat diet [45]. Experiments performed in our laboratory have demonstrated that the PPAR $\beta / \delta$ agonist GW501516 inhibits LPSinduced cytokine expression and secretion by preventing NF$\kappa \mathrm{B}$ activation in adipocytes [46]. Of note, NF- $\kappa \mathrm{B}$ activation by LPS requires mitogen-activated protein kinase (MAPK)extracellular signal-related kinase (ERK)1/2 (MEK1/2) activation, since inhibition of this pathway reduces LPS-induced cytokine production in adipocytes [47]. In agreement with this role of ERK1/2 in inflammation in adipocytes, the expression of proinflammatory cytokines in these cells drops when they are exposed to LPS in the presence of the MAPK pathway inhibitor U0126. Interestingly, in white adipose tissue from PPAR $\beta / \delta$-null mice we observed increased ERK1/2 phosphorylation and NF- $\kappa \mathrm{B}$ activity and higher expression of IL-6 compared with wild-type mice [46]. Moreover, in the white adipose tissue of a genetic model of obesity and diabetes, the Zucker diabetic fatty (ZDF) rat, the reduction in the expression of PPAR $\beta / \delta$ correlated with an increase in ERK1/2 phosphorylation and NF- $\kappa$ B activity. These findings suggest that $\mathrm{PPAR} \beta / \delta$ activation prevents LPS-induced NF$\kappa \mathrm{B}$ activation via ERK1/2, thereby reducing the production of proinflammatory cytokines involved in the development of insulin resistance.

In addition, $\operatorname{PPAR} \beta / \delta$ is involved in the phenotypic switch of adipose tissue-resident macrophages that modulates insulin sensitivity [48]. Thus, it has been suggested that macrophages infiltrated in adipose tissue from lean animals show an alternatively activated M2 phenotype [49] that is induced by Th2 cytokines, such as IL- 4 and IL13. These macrophages produce IL-10, a cytokine that inhibits inflammation [50]. In contrast, high-fat diets lead to infiltration of macrophages that show markers of classic activation by Th 1 cytokines, such as TNF- $\alpha$ and IL- $1 \beta$. These M1 phenotypic macrophages produce proinflammatory cytokines that lead to metabolic disturbances. In infiltrated macrophages in adipose tissue and liver, the signaling of Th2 cytokines is transduced by PPAR $\beta / \delta$ through a signal transducer and activator of transcription 6 (STAT6) binding site on its promoter, which induces alternative activation. The subsequent switch to the M2 phenotype prevents the inflammation caused by inflammatory mediators, such as FFA, in adipose tissue and liver. In agreement with this 
model, myeloid-specific PPAR $\beta / \delta^{-/-}$mice show adipocyte disfunction, insulin resistance, and hepatosteatosis [48].

\section{PPAR $\beta / \delta$, Inflammation, and Insulin Resistance in Skeletal Muscle Cells}

FFAs may cause insulin resistance in skeletal muscle through several mechanisms, including effects on metabolism [51, 52], signaling [53, 54], and mitochondrial function [55, 56]. In addition, FFAs activate proinflammatory pathways, linking the development of this pathology to a chronic low-grade systemic inflammatory response [57]. In addition to FFA-induced inflammation through TLR, an additional pathway leads to FFA-mediated inflammation. This pathway involves intracellular accumulation of fatty acid derivatives. Once fatty acids are taken up by skeletal muscle cells they are either stored as fatty acid derivatives or undergo $\beta$-oxidation in the mitochondria. In the presence of high plasma FFA, fatty acid flux in skeletal muscle cells exceeds its oxidation, which leads to the accumulation of fatty acid derivatives, such as diacylglycerol (DAG), which can then activate a number of different serine kinases that negatively regulate insulin action. Thus, DAG is a potent allosteric activator of protein kinase $\mathrm{C} \theta(\mathrm{PKC} \theta)$, which is the most abundant $\mathrm{PKC}$ isoform in skeletal muscle [58-60]. This PKC isoform inhibits the action of insulin by phosphorylating certain serine residues on insulin receptor substrate 1 (IRS1), including $\mathrm{Ser}^{307}$ in the rodent IRS-1 protein (reviewed in [61]). This phosphorylation impairs insulin-receptor signaling through several distinct mechanisms [62]. PKC $\theta$ also impairs insulin sensitivity by activating another serine kinase, I $\kappa \mathrm{B}$ kinase $\beta$ (IKK $\beta$ ) [63]. In addition to phosphorylating IRS-1 in $\mathrm{Ser}^{307}$, IKK $\beta$ phosphorylates I $\kappa \mathrm{B}$. Thus, it activates the proinflammatory transcription factor NF- $\kappa \mathrm{B}$, which has been linked to fatty acid-induced impairment of insulin action in skeletal muscle in rodents $[64,65]$. Once activated, $\mathrm{NF}-\kappa \mathrm{B}$ regulates the expression of multiple inflammatory mediators, including IL-6. This cytokine correlates strongly with insulin resistance and type 2 diabetes [66-68] and its plasma levels are 2-3 times higher in patients with obesity and type 2 diabetes than in lean control subjects [67].

Accumulation of fatty acid derivatives can be attenuated by mitochondrial $\beta$-oxidation. The rate-limiting step for $\beta$ oxidation of long-chain fatty acids is their transport into mitochondria via carnitine palmitoyltransferase-1 (CPT$1)$. The activity of this enzyme is inhibited by malonylCoA, the product of acetyl-CoA carboxylase, which, in turn, is inhibited by the AMP-activated protein kinase (AMPK). This kinase is a metabolic sensor that detects low ATP levels and increases oxidative metabolism [69], by reducing the levels of malonyl-CoA. Interestingly, activation of fatty acid oxidation by overexpressing CPT- 1 in cultured skeletal muscle cells [70] and in mouse skeletal muscle [71] improves lipid-induced insulin resistance. Hence, this approach may provide a valid therapeutic strategy to prevent this pathology. Activation of PPAR $\beta / \delta$ by its ligands (including GW501516) enhances fatty acid catabolism in adipose tissue and skeletal muscle, thereby delaying weight gain (for a review, see [72]). This increase in fatty acid oxidation in human skeletal muscle cells following PPAR $\beta / \delta$ activation by GW501516 is dependent on both PPAR $\beta / \delta$ and AMPK [73]. AMPK is activated by GW501516 by modulating the ATP : AMP ratio [73]. Despite these data, little information was available on whether the increase in fatty acid oxidation attained after $\operatorname{PPAR} \beta / \delta$ activation prevented fatty acidinduced inflammation and insulin resistance in skeletal muscle cells. However, we have recently reported that the PPAR $\beta / \delta$ ligand GW501516 prevented palmitate-induced inflammation and insulin resistance in skeletal muscle cells [74]. Treatment with GW501516 enhanced the expression of two-well known PPAR $\beta / \delta$-target genes involved in fatty acid oxidation, CPT- 1 and pyruvate dehydrogenase kinase 4 (PDK-4), and increased the phosphorylation of AMPK (Figure 2). This prevented the reduction in fatty acid oxidation caused by palmitate exposure. In agreement with these changes, GW501516 treatment reversed the increase in DAG and PKC $\theta$ activation caused by palmitate. These effects were abolished in the presence of the CPT-1 inhibitor etomoxir, thereby implicating increased fatty acid oxidation in the changes. Consistent with these findings, $\operatorname{PPAR} \beta / \delta$ activation by GW501516 blocked palmitate-induced NF- $\kappa$ B DNA-binding activity. Likewise, drug treatment inhibited the increase in IL-6 expression caused by palmitate in C2C12 myotubes and human skeletal muscle cells, as well as the protein secretion of this cytokine. Overall, these findings indicate that $\operatorname{PPAR} \beta / \delta$ attenuates fatty acid-induced NF- $\kappa \mathrm{B}$ activation and the subsequent development of insulin resistance in skeletal muscle cells by reducing DAG accumulation. To our knowledge no studies have assessed whether this mechanism operates in humans. However, since GW501516 increases CPT- 1 expression and palmitate oxidation in human skeletal muscle $[75,76]$, this possibility merits further exploration.

\section{PPAR $\beta / \delta$, Inflammation, and Heart Function}

The constant pumping of the heart requires a high energy supply, which is mainly met by fatty acids and glucose. The oxidation of fatty acids and glucose covers $65 \%$ and $30 \%$ of the energy demand of the adult heart, respectively [77]. The heart, in contrast to other tissues such as the brain, adapts its metabolism to substrate availability. For example, an increase in glucose utilization and a decrease in fatty acid oxidation is observed during cardiac hypertrophy and congestive heart failure [78-80]. PPAR $\beta / \delta$. is involved in the control of fatty acid oxidation in heart, which is similar to its role in skeletal muscle. We have reported that the levels of both PPAR $\alpha$ and PPAR $\beta / \delta$ are reduced in pressureoverload cardiac hypertrophy [81]. Therefore, the fall in the expression of both PPAR subtypes during the development of cardiac hypertrophy may be necessary to downregulate the expression of genes involved in fatty acid metabolism. Interestingly, the changes that cardiac hypertrophy causes in the expression of genes involved in fatty acid metabolism were not observed when NF- $\kappa \mathrm{B}$ activity was inhibited [82]. These data pointed to the involvement of NF- $\kappa \mathrm{B}$ in the changes. Therefore, we evaluated whether mechanisms 


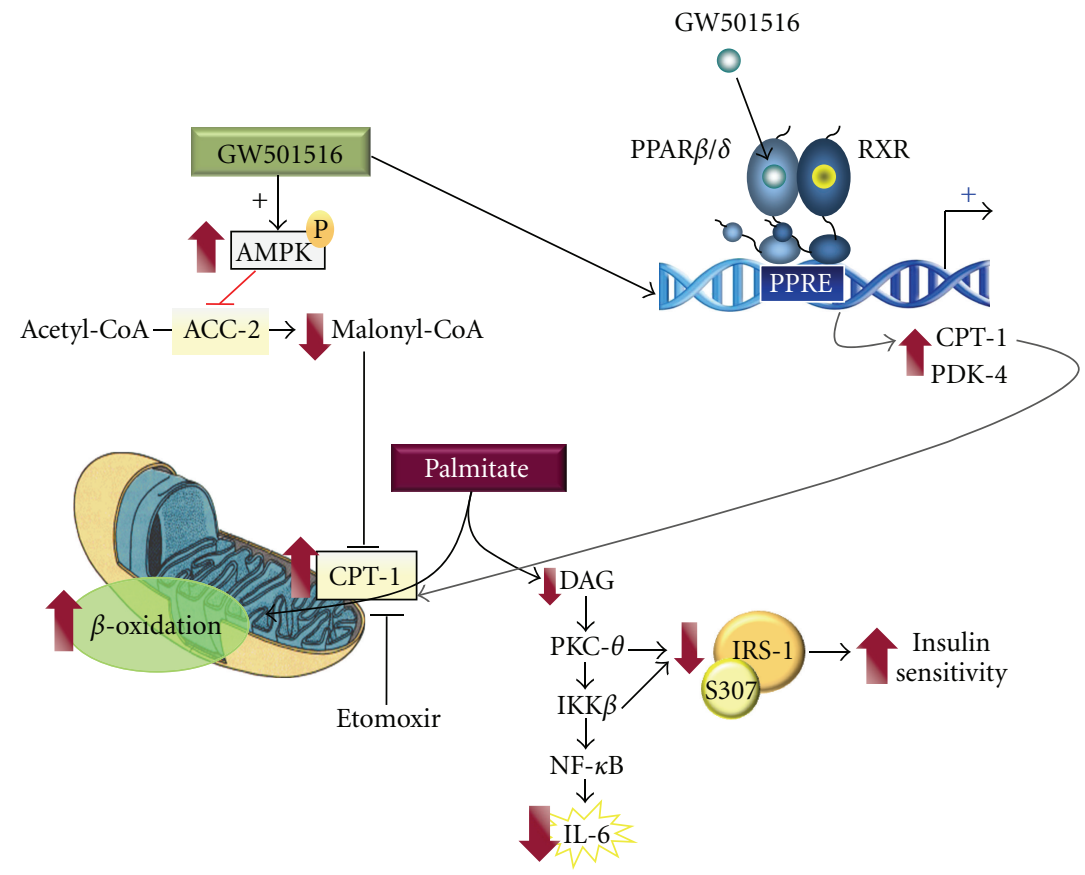

Figure 2: Potential mechanism of action involved in the reduction of insulin resistance and inflammation in skeletal muscle cells following PPAR $\beta / \delta$ activation by GW501516. ACC-2, acetyl-CoA carboxylase 2; AMPK, AMP-activated protein kinase; CPT-1, carnitine palmitoyltransferase-1; DAG, diacylglycerol; IKK $\beta$, I $\kappa$ B kinase $\beta$; IL-6, interleukin 6; IRS-1, Insulin Receptor Substrate 1; NF- $\kappa$ B, Nuclear Factor- $\kappa \mathrm{B}$; PDK-4, pyruvate dehydrogenase kinase 4; PKC $\theta$, protein kinase $\mathrm{C} \theta$.

such as protein-protein interaction between NF- $\kappa \mathrm{B}$ and PPAR contribute to the changes in the expression of genes involved in cardiac fatty acid metabolism, in addition to the reported reduction in the expression of PPARs during cardiac hypertrophy [83]. Using both in vitro and in vivo models of cardiac hypertrophy, we studied the contribution of NF- $\kappa \mathrm{B}$ activation to the downregulation of fatty acid oxidation during this process. Stimulation of rat neonatal cardiomyocytes with phenylephrine (PE), which leads to NF- $\kappa \mathrm{B}$ activation [84], caused cardiac hypertrophy that was accompanied by a fall in the expression of PDK-4 and palmitate oxidation. Furthermore, the reduction in the expression of PDK-4 and fatty acid oxidation observed in PE-stimulated rat neonatal cardiomyocytes was restored by $\mathrm{NF}-\kappa \mathrm{B}$ inhibitors. These findings and additional studies [85] pointed to the involvement of NF- $\kappa \mathrm{B}$ in the downregulation of fatty acid oxidation during the development of cardiac hypertrophy. In agreement with this idea, a study demonstrated that cardiomyocyte-restricted $\mathrm{PPAR} \beta / \delta$ deletion in heart of mice reduced myocardial fatty acid oxidation and the mRNA expression of genes involved in this process, such as $\mathrm{PDK}-4$, and led to cardiomyopathy [86]. The mechanism by which activation of $\mathrm{NF}-\kappa \mathrm{B}$ results in reduced expression of $\mathrm{PPAR} \beta / \delta$ target genes seems to involve reduced interaction of this PPAR subtype with its cis-regulatory element, since NF- $\kappa \mathrm{B}$ activation caused a dramatic reduction in the binding of $\operatorname{PPAR} \beta / \delta$ protein to the PPRE probe. This reduction was partially reversed by co-incubation of the cells with NF- $\kappa$ B inhibitors, which confirms the involvement of this transcription factor in the changes observed. Therefore, the reduced binding activity of $\mathrm{PPAR} \beta / \delta$ seems to be related to the activation of NF$\kappa \mathrm{B}$ in cardiac cells. However, the mechanism by which NF$\kappa \mathrm{B}$ activation prevented the interaction of $\mathrm{PPAR} \beta / \delta$ with its response element still had to be established. NF- $\kappa \mathrm{B}$ is present in the cytoplasm as an inactive heterodimer that consists mostly of the p50 and p65 subunits. However, after activation, this heterodimer translocates to the nucleus and regulates the expression of genes involved in inflammatory and immune processes. Our results indicated that once the p65 subunit of NF- $\kappa \mathrm{B}$ reaches the nucleus it interacts with $\operatorname{PPAR} \beta / \delta$. This association prevents $\operatorname{PPAR} \beta / \delta$ from binding to its response element, and thereby inhibits its ability to induce gene transcription, which leads to a reduction in the expression of PDK-4. In a recent study it has also been reported that $\mathrm{PPAR} \beta / \delta$ ligands and overexpression of this nuclear receptor suppressed myocardial inflammatory responses, such as the lipopolysaccharide-mediated production of TNF $\alpha$. This had beneficial effects on animals that had undergone ischemia/reperfusion injury or cardiac hypertrophy [87].

\section{PPAR $\beta / \delta$, Inflammation, and Atherosclerosis}

There is a strong relationship between circulating lipoproteins and atherosclerosis, since modified LDL-cholesterol particles are taken up by monocyte-derived macrophages, 
which leads to the formation of what are known as foam cells in the arterial intimal wall. Furthermore, these macrophages contribute to the inflammatory reaction by the production and secretion of numerous proinflammatory cytokines [88].

Treatment of obese rhesus monkeys, which are a model for human obesity and its associated metabolic disorders, with the $\mathrm{PPAR} \beta / \delta$ agonist GW501516 increased HDLcholesterol (79\%), and decreased triglycerides (56\%), LDLcholesterol (29\%), and fasting insulin levels (48\%) [22]. A decrease in proatherogenic small dense LDL was also observed in treated animals [89]. It has been suggested that the increase in HDL-cholesterol levels after PPAR $\beta / \delta$ treatment is caused by enhanced cholesterol efflux, which is stimulated by higher expression of the reverse cholesterol transporter ATP-binding cassette A1 (ABCA1) in several tissues, including human and mouse macrophages and intestinal cells and fibroblasts [90, 91]. Apart from these beneficial effects of $\mathrm{PPAR} \beta / \delta$ activation on HDL levels, treatment with this compound also increased HDL particle size in primates [92]. This effect is thought to be protective against the progression of coronary artery disease in humans [93]. In addition, $\mathrm{PPAR} \beta / \delta$ activation reduces cholesterol absorption through a mechanism that may at least partly involve reduced intestinal expression of Niemann-Pick C1like 1 (Npc1l1), which is the proposed target for ezetimibe, an inhibitor of cholesterol absorption [91]. Furthermore, deletion of $\mathrm{PPAR} \beta / \delta$ in mice led to enhanced LDL and triglyceride levels [94]. The administration of a $\operatorname{PPAR} \beta / \delta$ agonist to obese and diabetic $d b / d b$ mice slightly increased HDL particles, without affecting triglyceride levels [90]. In a shorter treatment with GW501516, a reduction in plasma free fatty acids and triglyceride levels was observed in $d b / d b$ mice, but not in mice exposed to a high-fat diet [95]. In humans, there are conflicting reports on whether $\mathrm{PPAR} \beta / \delta$ polymorphisms are associated with changes in plasma lipoproteins. Thus, while some authors found an association between a $\operatorname{PPAR} \beta / \delta$ polymorphism and plasma lipids [96], this was not confirmed by others [97]. These discrepancies could be caused by differences in sex or the influence of gene-environment interactions, since a recent study reported that the association between the $\operatorname{PPAR} \beta / \delta$ $87 \mathrm{~T}>\mathrm{C}$ polymorphism and plasma HDL-cholesterol might be sex-specific, with women showing a stronger association. This association was only observed in subjects consuming a low-fat diet [98]. The authors concluded that the presence of the $\mathrm{PPAR} \beta / \delta-87 \mathrm{~T}>\mathrm{C}$ polymorphism, which may result in enhanced $\operatorname{PPAR} \beta / \delta$ activity, is associated with lower risk of suffering from metabolic syndrome and that this association depends on the amount of fat consumed. In summary, the findings that are currently available on the effects of PPAR $\beta / \delta$ activation on lipoprotein metabolism are so promising that $\operatorname{PPAR} \beta / \delta$ drugs are now in clinical trials for the treatment of human dyslipidemia.

During the development of atherosclerosis, macrophages contribute to inflammation by producing and secreting numerous proinflammatory cytokines [99]. Activated macrophages express the three PPAR isotypes. Whereas the roles of the PPAR $\alpha$ and $\gamma$ isotypes in macrophage cholesterol homeostasis are well established, the role of
$\operatorname{PPAR} \beta / \delta$ remains controversial. Oliver et al. [100] showed that treatment of THP-1 human monocytes with the $\operatorname{PPAR} \beta / \delta$ ligand GW501516 enhanced the expression of the reverse cholesterol transporter ABCA1 and induced apoA1specific cholesterol efflux. Opposite findings were reported by Vosper et al. [101]. They found that treatment with a different $\operatorname{PPAR} \beta / \delta$ ligand promoted lipid accumulation in human macrophages (THP-1) exposed to oxidized LDL by increasing the expression of the class $\mathrm{A}$ and $\mathrm{B}$ scavenger receptors (SR-A and CD-36) and the lipid storage-related genes $a P 2$ and adipophilin [101]. Finally, two studies showed that cholesterol efflux or accumulation was not affected by $\operatorname{PPAR} \beta / \delta$ depletion or by $\operatorname{PPAR} \beta / \delta$ ligands in murine macrophages $[102,103]$. Collectively, these findings suggest that PPAR $\beta / \delta$ does not affect cholesterol metabolism in mice. However, additional studies are needed to establish the role of this nuclear receptor in human macrophage cholesterol metabolism.

It is accepted that inflammation links dyslipidemia to atherosclerotic plaque formation [104]. Several studies have described a role for $\operatorname{PPAR} \beta / \delta$ in inflammation in atherosclerosis. For instance, atherosclerosis-prone LDL receptor-null mice transplanted with bone marrow from $P P A R \beta / \delta$-deficient mice and fed a high-cholesterol diet showed smaller vascular lesions (50\% reduction) than wild-type recipient controls [102], whereas no significant differences between the two groups were found for plasma cholesterol levels. However, PPAR $\beta / \delta$-null macrophages had lower expression of the inflammation markers MCP-1, interleukin $1 \beta$ (IL-1 $\beta$ ), and metalloproteinase 9 (MMP9) $[102]$. In contrast, $\operatorname{PPAR} \beta / \delta$ ligands suppressed the expression of these inflammation markers in wild-type macrophages. These findings led to the suggestion that $\operatorname{PPAR} \beta / \delta$ regulates an inflammatory switch by binding or releasing the anti-inflammatory transcriptional suppressor protein B cell lymphoma-6 (BCL-6) $[72,102]$. In the absence of the ligand, $\mathrm{PPAR} \beta / \delta$ sequesters BCL- 6 , which leads to inflammation. However, in the presence of the ligand, $\operatorname{PPAR} \beta / \delta$ releases BCL- 6 , which then represses inflammatory gene expression. Similarly, deletion of PPAR $\beta / \delta$ also releases BCL-6, which has anti-inflammatory effects. Therefore, this mechanism may explain how both $\operatorname{PPAR} \beta / \delta$ activation and the deletion of this nuclear receptor result in a similar reduction of inflammation. Whether additional mechanisms may contribute to the anti-inflammatory effect of the PPAR $\beta / \delta$ isotype remains to be studied. It should be noted that part of the anti-inflammatory effects of PPAR $\gamma$ agonists used at high concentrations in macrophages has been attributed to the activation of PPAR $\beta / \delta$ [105], since at high concentrations, PPAR $\gamma$ ligands may activate both PPAR isotypes. Although these findings indicate that $\operatorname{PPAR} \beta / \delta$ activation may be beneficial in the treatment of atherosclerosis, in vivo studies are contradictory. Thus, Li et al. [103] reported no effect of the PPAR $\beta / \delta$ agonist GW0742 on atherosclerotic lesion size in male $\mathrm{LDL}^{-/-}$mice fed an atherogenic diet $(1.25 \%$ cholesterol). In contrast, Graham et al. [106] reported that administration of GW0742 to female $\mathrm{LDL}^{-/-}$mice fed an atherogenic diet $(0.25 \%$ cholesterol $)$ reduced atherosclerosis by $30 \%$. Differences between these two studies 
(sex, cholesterol supplementation, or drug doses) may explain the contradictory results. Overall, these data suggest that $\operatorname{PPAR} \beta / \delta$ agonists have anti-inflammatory effects in vivo, but not sufficient to inhibit the development of atherosclerosis in extreme hypercholesterolemic animal models of the disease. Additional studies will be needed to determine the exact role of $\mathrm{PPAR} \beta / \delta$ in modulating the development of atherosclerosis can be determined.

\section{Concluding Remarks}

The treatment and prevention of obesity, insulin resistance, and type 2 diabetes mellitus requires lifestyle changes, including weight reduction, increased physical activity and diet. However, many patients cannot control these pathologies with lifestyle modification and there is a need for drugs to manage them. Activation of $\operatorname{PPAR} \beta / \delta$ may become a pharmacological strategy for treating these disorders. This treatment improves atherogenic dyslipidemia by reducing plasma triglyceride levels and enhancing plasma HDLcholesterol levels. $\operatorname{PPAR} \beta / \delta$ also regulates the availability of BCL-6, an inflammatory suppressor protein that is released upon ligand binding to $\mathrm{PPAR} \beta / \delta$, thereby behaving as an "anti-inflammatory switch" to control macrophageelicited inflammation and atherogenesis. In skeletal muscle, $\operatorname{PPAR} \beta / \delta$ ligands may also upregulate fatty acid transport and oxidation, which reduces fatty acid-induced inflammation and insulin resistance. In adipose tissue, they prevent the activation of NF- $\kappa \mathrm{B}$ by reducing the production of inflammatory cytokines. In addition, $\mathrm{PPAR} \beta / \delta$ activation in the heart prevents cardiac hypertrophy and improves cardiomyopathy.

As with any drug designed for human therapy, a great deal of research will be needed on the efficacy and safety of $\operatorname{PPAR} \beta / \delta$ activators before they reach clinical use. For instance, the ability of PPAR $\beta / \delta$ activators to raise HDLcholesterol levels in rodents has been demonstrated in primates, but the effects of these drugs on the prevention of obesity in rodents were not observed in primates. This suggests that weight reduction caused by PPAR $\beta / \delta$ ligands in mice depends on their effects on thermogenesis, which is a minor mechanism of energy expenditure in humans and primates. Safety issues have also been raised regarding the connection between PPAR $\beta / \delta$ ligands and carcinogenesis, particularly in animal models [107-110]. However, synthetic $\operatorname{PPAR} \gamma$ and $\alpha$ ligands induce carcinogenesis in rodents, but do not present these effects in humans [111, 112]. In summary, clinical studies are required to determine the efficacy and safety of PPAR $\beta / \delta$ ligands.

\section{Acknowledgments}

The authors' work summarized in this paper was supported by Grants from the Ministerio de Ciencia e Innovación of Spain (SAF2006-01475 and SAF2009-06939). CIBER de Diabetes y Enfermedades Metabólicas Asociadas (CIBERDEM) is an Instituto de Salud Carlos III project. T. Coll and L. Serrano were supported by grants from the Ministerio de
Ciencia e Innovación of Spain. We thank the Language Advisory Service of the University of Barcelona for his helpful assistance.

\section{References}

[1] J. Plutzky, "Expansion and contraction: the mighty, mighty fatty acid," Nature Medicine, vol. 15, no. 6, pp. 618-619, 2009.

[2] S. Kersten, B. Desvergne, and W. Wahli, "Roles of PPARS in health and disease," Nature, vol. 405, no. 6785, pp. 421-424, 2000.

[3] A. Castrillo and P. Tontonoz, "Nuclear receptors in macrophage biology: at the crossroads of lipid metabolism and inflammation," Annual Review of Cell and Developmental Biology, vol. 20, pp. 455-480, 2004.

[4] G. Chinetti, J.-C. Fruchart, and B. Staels, "Peroxisome proliferator-activated receptors (PPARs): nuclear receptors at the crossroads between lipid metabolism and inflammation," Inflammation Research, vol. 49, no. 10, pp. 497-505, 2000.

[5] J. N. Feige, L. Gelman, L. Michalik, B. Desvergne, and W. Wahli, "From molecular action to physiological outputs: peroxisome proliferator-activated receptors are nuclear receptors at the crossroads of key cellular functions," Progress in Lipid Research, vol. 45, no. 2, pp. 120-159, 2006.

[6] I. Zamir, J. Zhang, and M. A. Lazar, "Stoichiometric and steric principles governing repression by nuclear hormone receptors," Genes and Development, vol. 11, no. 7, pp. 835846, 1997.

[7] R. A. Daynes and D. C. Jones, "Emerging roles of PPARs in inflammation and immunity," Nature Reviews Immunology, vol. 2, no. 10, pp. 748-759, 2002.

[8] Y. Kamei, L. Xu, T. Heinzel et al., "A CBP integrator complex mediates transcriptional activation and AP-1 inhibition by nuclear receptors," Cell, vol. 85, no. 3, pp. 403-414, 1996.

[9] M. Li, G. Pascual, and C. K. Glass, "Peroxisome proliferatoractivated receptor $\gamma$-dependent repression of the inducible nitric oxide synthase gene," Molecular and Cellular Biology, vol. 20, no. 13, pp. 4699-4707, 2000.

[10] P. Delerive, K. De Bosscher, S. Besnard et al., "Peroxisome proliferator-activated receptor $\alpha$ negatively regulates the vascular inflammatory gene response by negative crosstalk with transcription factors NF- $\kappa \mathrm{B}$ and AP-1," Journal of Biological Chemistry, vol. 274, no. 45, pp. 32048-32054, 1999.

[11] P. Delerive, F. Martin-Nizard, G. Chinetti et al., "Peroxisome proliferator-activated receptor activators inhibit thrombin- induced endothelin-1 production in human vascular endothelial cells by inhibiting the activator protein-1 signaling pathway," Circulation Research, vol. 85, no. 5, pp. 394-402, 1999.

[12] P. Desreumaux, L. Dubuquoy, S. Nutten et al., "Attenuation of colon inflammation through activators of the retinoid $\mathrm{X}$ receptor (RXR)/peroxisome proliferator-activated receptor $\gamma$ $(\operatorname{PPAR} \gamma)$ heterodimer. A basis for new therapeutic strategies," Journal of Experimental Medicine, vol. 193, no. 7, pp. 827838, 2001.

[13] T. E. Johnson, M. K. Holloway, R. Vogel et al., "Structural requirements and cell-type specificity for ligand activation of peroxisome proliferator-activated receptors," Journal of Steroid Biochemistry and Molecular Biology, vol. 63, no. 1-3, pp. 1-8, 1997.

[14] J. Auwerx, E. Baulieu, M. Beato et al., "A unified nomenclature system for the nuclear receptor superfamily," Cell, vol. 97, no. 2, pp. 161-163, 1999. 
[15] O. Braissant, F. Foufelle, C. Scotto, M. Dauça, and W. Wahli, "Differential expression of peroxisome proliferator-activated receptors (PPARs): tissue distribution of PPAR- $\alpha,-\beta$, and $-\gamma$ in the adult rat," Endocrinology, vol. 137, no. 1, pp. 354-366, 1996.

[16] S. A. Kliewer, B. M. Forman, B. Blumberg et al., "Differential expression and activation of a family of murine peroxisome proliferator-activated receptors," Proceedings of the National Academy of Sciences of the United States of America, vol. 91, no. 15, pp. 7355-7359, 1994.

[17] Y. Barak, D. Liao, W. He et al., "Effects of peroxisome proliferator-activated receptor $\delta$ on placentation, adiposity, and colorectal cancer," Proceedings of the National Academy of Sciences of the United States of America, vol. 99, no. 1, pp. 303-308, 2002.

[18] J. M. Peters, S. S. T. Lee, W. Li et al., "Growths, adipose, brain, and skin alterations resulting from targeted disruption of the mouse peroxisome proliferator-activated receptor $\beta(\delta)$," Molecular and Cellular Biology, vol. 20, no. 14, pp. 5119-5128, 2000.

[19] N. S. Tan, L. Michalik, N. Noy et al., "Critical roles of $\operatorname{PPAR} \beta / \delta$ in keratinocyte response to inflammation," Genes and Development, vol. 15, no. 24, pp. 3263-3277, 2001.

[20] L. Michalik, J. Auwerx, J. P. Berger et al., "International union of pharmacology. LXI. Peroxisome proliferator-activated receptors," Pharmacological Reviews, vol. 58, no. 4, pp. 726741, 2006.

[21] T. M. Willson, M. H. Lambert, and S. A. Kliewer, "Peroxisome proliferator-activated receptor $\gamma$ and metabolic disease," Annual Review of Biochemistry, vol. 70, pp. 341-367, 2001.

[22] W. R. Oliver Jr., J. L. Shenk, M. R. Snaith et al., "A selective peroxisome proliferator-activated receptor $\delta$ agonist promotes reverse cholesterol transport," Proceedings of the National Academy of Sciences of the United States of America, vol. 98, no. 9, pp. 5306-5311, 2001.

[23] C. Dreyer, G. Krey, H. Keller, F. Givel, G. Helftenbein, and W. Wahli, "Control of the peroxisomal $\beta$-oxidation pathway by a novel family of nuclear hormone receptors," Cell, vol. 68, no. 5, pp. 879-887, 1992.

[24] I. Takada, R. T. Yu, H. E. Xu et al., "Alteration of a single amino acid in peroxisome proliferator-activated receptor$\alpha(\operatorname{PPAR} \alpha)$ generates a PPAR $\delta$ phenotype," Molecular Endocrinology, vol. 14, no. 5, pp. 733-740, 2000.

[25] H. E. Xu, M. H. Lambert, V. G. Montana et al., "Molecular recognition of fatty acids by peroxisome proliferatoractivated receptors," Molecular Cell, vol. 3, no. 3, pp. 397-403, 1999.

[26] B. M. Forman, B. Ruan, J. Chen, G. J. Schroepfer Jr., and R. M. Evans, "The orphan nuclear receptor LXRa is positively and negatively regulated by distinct products of mevalonate metabolism," Proceedings of the National Academy of Sciences of the United States of America, vol. 94, no. 20, pp. 10588 10593, 1997.

[27] K. Yu, W. Bayona, C. B. Kallen et al., "Differential activation of peroxisome proliferator-activated receptors by eicosanoids," Journal of Biological Chemistry, vol. 270, no. 41, pp. 23975-23983, 1995.

[28] G. Krey, O. Braissant, F. L'Horset et al., "Fatty acids, eicosanoids, and hypolipidemic agents identified as ligands of peroxisome proliferator-activated receptors by coactivatordependent receptor ligand assay," Molecular Endocrinology, vol. 11, no. 6, pp. 779-791, 1997.
[29] N. Shaw, M. Elholm, and N. Noy, "Retinoic acid is a high affinity selective ligand for the peroxisome proliferatoractivated receptor $\beta / \delta$," Journal of Biological Chemistry, vol. 278, no. 43, pp. 41589-41592, 2003.

[30] A. Chawla, C.-H. Lee, Y. Barak et al., "PPAR $\delta$ is a very low-density lipoprotein sensor in macrophages," Proceedings of the National Academy of Sciences of the United States of America, vol. 100, no. 3, pp. 1268-1273, 2003.

[31] M. L. Sznaidman, C. D. Haffner, P. R. Maloney et al., "Novel selective small molecule agonists for peroxisome proliferatoractivated receptor $\delta(\operatorname{PPAR} \delta)$ - synthesis and biological activity," Bioorganic and Medicinal Chemistry Letters, vol. 13, no. 9, pp. 1517-1521, 2003.

[32] J. Berger, M. D. Leibowitz, T. W. Doebber et al., "Novel peroxisome proliferator-activated receptor (PPAR) $\gamma$ and PPAR $\delta$ ligands produce distinct biological effects," Journal of Biological Chemistry, vol. 274, no. 10, pp. 6718-6725, 1999.

[33] B. G. Shearer, D. J. Steger, J. M. Way et al., "Identification and characterization of a selective peroxisome proliferatoractivated receptor $\beta / \delta$ (NR1C2) antagonist," Molecular Endocrinology, vol. 22, no. 2, pp. 523-529, 2008.

[34] P. Mathieu, I. Lemieux, and J. P. Despres, "Obesity, inflammation, and cardiovascular risk," Clinical Pharmacology and Therapeutics, vol. 87, no. 4, pp. 407-416, 2010.

[35] K. L. Spalding, E. Arner, P. O. Westermark et al., "Dynamics of fat cell turnover in humans," Nature, vol. 453, no. 7196, pp. 783-787, 2008.

[36] B. Gustafson, S. Gogg, S. Hedjazifar, L. Jenndahl, A. Hammarstedt, and U. Smith, "Inflammation and impaired adipogenesis in hypertrophic obesity in man," American Journal of Physiology, vol. 297, no. 5, pp. E999-E1003, 2009.

[37] M. Roden, T. B. Price, G. Perseghin et al., "Mechanism of free fatty acid-induced insulin resistance in humans," Journal of Clinical Investigation, vol. 97, pp. 2859-2865, 1996.

[38] G. Boden, "Role of fatty acids in the pathogenesis of insulin resistance and NIDDM," Diabetes, vol. 46, no. 1, pp. 3-10, 1997.

[39] G. Boden, F. Jadali, J. White et al., "Effects of fat on insulinstimulated carbohydrate metabolism in normal men," Journal of Clinical Investigation, vol. 88, no. 3, pp. 960-966, 1991.

[40] P. Mathieu, P. Pibarot, and J.-P. Després, "Metabolic syndrome: the danger signal in atherosclerosis," Vascular Health and Risk Management, vol. 2, no. 3, pp. 285-302, 2006.

[41] H. Shi, M. V. Kokoeva, K. Inouye, I. Tzameli, H. Yin, and J. S. Flier, "TLR4 links innate immunity and fatty acid-induced insulin resistance," Journal of Clinical Investigation, vol. 116, no. 11, pp. 3015-3025, 2006.

[42] S. Akira, S. Uematsu, and O. Takeuchi, "Pathogen recognition and innate immunity," Cell, vol. 124, no. 4, pp. 783-801, 2006.

[43] S. E. Shoelson, J. Lee, and A. B. Goldfine, "Inflammation and insulin resistance," Journal of Clinical Investigation, vol. 116, no. 7, pp. 1793-1801, 2006.

[44] M. T. A. Nguyen, S. Favelyukis, A.-K. Nguyen et al., "A subpopulation of macrophages infiltrates hypertrophic adipose tissue and is activated by free fatty acids via toll-like receptors 2 and 4 and JNK-dependent pathways," Journal of Biological Chemistry, vol. 282, no. 48, pp. 35279-35292, 2007.

[45] P. D. Cani, J. Amar, M. A. Iglesias et al., "Metabolic endotoxemia initiates obesity and insulin resistance," Diabetes, vol. 56, no. 7, pp. 1761-1772, 2007. 
[46] R. Rodríguez-Calvo, L. Serrano, T. Coll et al., "Activation of peroxisome proliferator-activated receptor $\beta / \delta$ inhibits lipopolysaccharide-induced cytokine production in adipocytes by lowering nuclear factor- $\kappa \mathrm{B}$ activity via extracellular signal-related kinase 1/2," Diabetes, vol. 57, no. 8, pp. 2149-2157, 2008.

[47] S. Chung, K. LaPoint, K. Martinez, A. Kennedy, M. B. Sandberg, and M. K. McIntosh, "Preadipocytes mediate lipopolysaccharide-induced inflammation and insulin resistance in primary cultures of newly differentiated human adipocytes," Endocrinology, vol. 147, no. 11, pp. 5340-5351, 2006.

[48] K. Kang, S. M. Reilly, V. Karabacak et al., "Adipocyte-derived Th2 cytokines and myeloid PPAR $\delta$ regulate macrophage polarization and insulin sensitivity," Cell Metabolism, vol. 7, no. 6, pp. 485-495, 2008.

[49] C. N. Lumeng, S. M. Deyoung, and A. R. Saltiel, "Macrophages block insulin action in adipocytes by altering expression of signaling and glucose transport proteins," American Journal of Physiology, vol. 292, no. 1, pp. E166E174, 2007.

[50] S. Gordon, "Alternative activation of macrophages," Nature Reviews Immunology, vol. 3, no. 1, pp. 23-35, 2003.

[51] M. Roden, G. Perseghin, K. F. Petersen et al., "The roles of insulin and glucagon in the regulation of hepatic glycogen synthesis and turnover in humans," Journal of Clinical Investigation, vol. 97, no. 3, pp. 642-648, 1996.

[52] E. P. Haber, S. M. Hirabara, A. D. Gomes, R. Curi, A. R. Carpinelli, and C. R. O. Carvalho, "Palmitate modulates the early steps of insulin signalling pathway in pancreatic islets," FEBS Letters, vol. 544, no. 1-3, pp. 185-188, 2003.

[53] S. M. Hirabara, L. R. Silveira, F. Abdulkader, C. R. O. Carvalho, J. Procopio, and R. Curi, "Time-dependent effects of fatty acids on skeletal muscle metabolism," Journal of Cellular Physiology, vol. 210, no. 1, pp. 7-15, 2007.

[54] L. R. Silveira, J. Fiamoncini, S. M. Hirabara et al., "Updating the effects of fatty acids on skeletal muscle," Journal of Cellular Physiology, vol. 217, no. 1, pp. 1-12, 2008.

[55] P. Schrauwen, V. Schrauwen-Hinderling, J. Hoeks, and M. K. C. Hesselink, "Mitochondrial dysfunction and lipotoxicity," Biochimica et Biophysica Acta, vol. 1801, no. 3, pp. 266-271, 2009.

[56] S. M. Hirabara, R. Curi, and P. Maechler, "Saturated fatty acid-induced insulin resistance is associated with mitochondrial dysfunction in skeletal muscle cells," Journal of Cellular Physiology, vol. 222, no. 1, pp. 187-194, 2010.

[57] K. E. Wellen and G. S. Hotamisligil, "Inflammation, stress, and diabetes," Journal of Clinical Investigation, vol. 115, no. 5, pp. 1111-1119, 2005.

[58] M. E. Griffin, M. J. Marcucci, G. W. Cline et al., "Free fatty acid-induced insulin resistance is associated with activation of protein kinase $\mathrm{C} \theta$ and alterations in the insulin signaling cascade," Diabetes, vol. 48, no. 6, pp. 1270-1274, 2000.

[59] R. N. Cortright, J. L. Azevedo Jr., Q. Zhou et al., "Protein kinase C modulates insulin action in human skeletal muscle," American Journal of Physiology, vol. 278, no. 3, pp. E553E562, 2000.

[60] S. I. Itani, Q. Zhou, W. J. Pories, K. G. MacDonald, and G. L. Dohm, "Involvement of protein kinase $\mathrm{C}$ in human skeletal muscle insulin resistance and obesity," Diabetes, vol. 49, no. 8, pp. 1353-1358, 2000.

[61] P. Gual, Y. Le Marchand-Brustel, and J.-F. Tanti, "Positive and negative regulation of insulin signaling through IRS-1 phosphorylation," Biochimie, vol. 87, no. 1, pp. 99-109, 2005.
[62] G. S. Hotamisligil, P. Peraldi, A. Budavari, R. Ellis, M. F. White, and B. M. Spiegelman, "IRS-1-mediated inhibition of insulin receptor tyrosine kinase activity in TNF- $\alpha$ - and obesity-induced insulin resistance," Science, vol. 271, no. 5249, pp. 665-668, 1996.

[63] G. Perseghin, K. Petersen, and G. I. Shulman, "Cellular mechanism of insulin resistance: potential links with inflammation," International Journal of Obesity, vol. 27, supplement 3, pp. S6-S11, 2003.

[64] J. K. Kim, Y.-J. Kim, J. J. Fillmore et al., "Prevention of fatinduced insulin resistance by salicylate," Journal of Clinical Investigation, vol. 108, no. 3, pp. 437-446, 2001.

[65] M. Yuan, N. Konstantopoulos, J. Lee et al., "Reversal of obesity- and diet-induced insulin resistance with salicylates or targeted disruption of Ikk $\beta$," Science, vol. 293, no. 5535, pp. 1673-1677, 2001.

[66] J. C. Pickup, M. B. Mattock, G. D. Chusney, and D. Burt, "NIDDM as a disease of the innate immune system: association of acute- phase reactants and interleukin-6 with metabolic syndrome X," Diabetologia, vol. 40, no. 11, pp. 1286-1292, 1997.

[67] P. A. Kern, S. Ranganathan, C. Li, L. Wood, and G. Ranganathan, "Adipose tissue tumor necrosis factor and interleukin-6 expression in human obesity and insulin resistance," American Journal of Physiology, vol. 280, no. 5, pp. E745-E751, 2001.

[68] A. D. Pradhan, J. E. Manson, N. Rifai, J. E. Buring, and P. M. Ridker, "C-reactive protein, interleukin 6 , and risk of developing type 2 diabetes mellitus," Journal of the American Medical Association, vol. 286, no. 3, pp. 327-334, 2001.

[69] R. M. Reznick and G. I. Shulman, "The role of AMP-activated protein kinase in mitochondrial biogenesis," Journal of Physiology, vol. 574, no. 1, pp. 33-39, 2006.

[70] D. Sebastián, L. Herrero, D. Serra, G. Asins, and F. G. Hegardt, "CPT I overexpression protects L6E9 muscle cells from fatty acid-induced insulin resistance," American Journal of Physiology, vol. 292, no. 3, pp. E677-E686, 2007.

[71] C. R. Bruce, A. J. Hoy, N. Turner et al., "Overexpression of carnitine palmitoyltransferase-1 in skeletal muscle is sufficient to enhance fatty acid oxidation and improve highfat diet-induced insulin resistance," Diabetes, vol. 58, no. 3, pp. 550-558, 2009.

[72] G. D. Barish, V. A. Narkar, and R. M. Evans, "PPAR $\delta$ : a dagger in the heart of the metabolic syndrome," Journal of Clinical Investigation, vol. 116, no. 3, pp. 590-597, 2006.

[73] D. K. Krämer, L. Al-Khalili, B. Guigas, Y. Leng, P. M. GarciaRoves, and A. Krook, "Role of AMP kinase and PPAR $\delta$ in the regulation of lipid and glucose metabolism in human skeletal muscle," Journal of Biological Chemistry, vol. 282, no. 27, pp. 19313-19320, 2007.

[74] T. Coll, D. Álvarez-Guardia, E. Barroso et al., "Activation of peroxisome proliferator-activated receptor- $\delta$ by GW501516 prevents fatty acid-induced nuclear factor- $\kappa \mathrm{B}$ activation and insulin resistance in skeletal muscle cells," Endocrinology, vol. 151, no. 4, pp. 1560-1569, 2010.

[75] U. Risérus, D. Sprecher, T. Johnson et al., "Activation of peroxisome proliferator-activated receptor (PPAR) $\delta$ promotes reversal of multiple metabolic abnormalities, reduces oxidative stress, and increases fatty acid oxidation in moderately obese men," Diabetes, vol. 57, no. 2, pp. 332-339, 2008.

[76] D. L. Sprecher, C. Massien, G. Pearce et al., "Triglyceride: high-density lipoprotein cholesterol effects in healthy 
subjects administered a peroxisome proliferator activated receptor $\delta$ agonist," Arteriosclerosis, Thrombosis, and Vascular Biology, vol. 27, no. 2, pp. 359-365, 2007.

[77] P. M. Barger, J. M. Brandt, T. C. Leone, C. J. Weinheimer, and D. P. Kelly, "Deactivation of peroxisome proliferatoractivated receptor- $\alpha$ during cardiac hypertrophic growth," Journal of Clinical Investigation, vol. 105, no. 12, pp. 17231730, 2000.

[78] M. F. Allard, P. G. Emanuel, J. A. Russell, S. P. Bishop, S. B. Digerness, and P. G. Anderson, "Preischemic glycogen reduction or glycolytic inhibition improves postischemic recovery of hypertrophied rat hearts," American Journal of Physiology, vol. 267, no. 1, pp. H66-H74, 1994.

[79] Y. Kagaya, Y. Kanno, D. Takeyama et al., "Effects of longterm pressure overload on regional myocardial glucose and free fatty acid uptake in rats: a quantitative autoradiographic study," Circulation, vol. 81, no. 4, pp. 1353-1361, 1990.

[80] T. Doenst, G. W. Goodwin, A. M. Cedars, M. Wang, S. Stepkowski, and H. Taegtmeyer, "Load-induced changes in vivo alter substrate fluxes and insulin responsiveness of rat heart in vitro," Metabolism: Clinical and Experimental, vol. 50, no. 9, pp. 1083-1090, 2001.

[81] A. Planavila, J. C. Laguna, and M. Vázquez-Carrera, "Nuclear factor- $\kappa \mathrm{B}$ activation leads to down-regulation of fatty acid oxidation during cardiac hypertrophy," Journal of Biological Chemistry, vol. 280, no. 17, pp. 17464-17471, 2005.

[82] A. Planavila, J. C. Laguna, and M. Vázquez-Carrera, "Atorvastatin improves peroxisome proliferator-activated receptor signaling in cardiac hypertrophy by preventing nuclear factor- $\kappa \mathrm{B}$ activation," Biochimica et Biophysica Acta, vol. 1687, no. 1-3, pp. 76-83, 2005.

[83] A. Planavila, J. C. Laguna, and M. Vázquez-Carrera, "Nuclear factor- $\kappa \mathrm{B}$ activation leads to down-regulation of fatty acid oxidation during cardiac hypertrophy," Journal of Biological Chemistry, vol. 280, no. 17, pp. 17464-17471, 2005.

[84] S. Hirotani, K. Otsu, K. Nishida et al., "Involvement of nuclear factor- $\kappa \mathrm{B}$ and apoptosis signal-regulating kinase 1 in G-protein-coupled receptor agonist-induced cardiomyocyte hypertrophy," Circulation, vol. 105, no. 4, pp. 509-515, 2002.

[85] P. J. H. Smeets, B. E. J. Teunissen, A. Planavila et al., "Inflammatory pathways are activated during cardiomyocyte hypertrophy and attenuated by peroxisome proliferatoractivated receptors PPAR $\alpha$ and PPAR $\delta$," Journal of Biological Chemistry, vol. 283, no. 43, pp. 29109-29118, 2008.

[86] L. Cheng, G. Ding, Q. Qin et al., "Cardiomyocyte-restricted peroxisome proliferator-activated receptor- $\delta$ deletion perturbs myocardial fatty acid oxidation and leads to cardiomyopathy," Nature Medicine, vol. 10, no. 11, pp. 1245-1250, 2004.

[87] G. Ding, L. Cheng, Q. Qin, S. Frontin, and Q. Yang, "PPAR $\delta$ modulates lipopolysaccharide-induced TNF $\alpha$ inflammation signaling in cultured cardiomyocytes," Journal of Molecular and Cellular Cardiology, vol. 40, no. 6, pp. 821-828, 2006.

[88] P. Libby, P. M. Ridker, G. K. Hansson, and Leducq Transatlantic Network on Atherothrombosis, "Inflammation in atherosclerosis: from pathophysiology to practice," Journal of Molecular and Cellular Cardiology, vol. 54, no. 23, pp. 21292138, 2009.

[89] W. R. Oliver Jr., J. L. Shenk, M. R. Snaith et al., "A selective peroxisome proliferator-activated receptor $\delta$ agonist promotes reverse cholesterol transport," Proceedings of the National Academy of Sciences of the United States of America, vol. 98, no. 9, pp. 5306-5311, 2001.
[90] M. D. Leibowitz, C. Fiévet, N. Hennuyer et al., "Activation of PPAR $\delta$ alters lipid metabolism in db/db mice," FEBS Letters, vol. 473, no. 3, pp. 333-336, 2000.

[91] J. N. Van Der Veen, J. K. Kruit, R. Havinga et al., "Reduced cholesterol absorption upon $\operatorname{PPAR} \delta$ activation coincides with decreased intestinal expression of NPC1L1," Journal of Lipid Research, vol. 46, no. 3, pp. 526-534, 2005.

[92] J. M. Wallace, M. Schwarz, P. Coward et al., "Effects of peroxisome proliferator-activated receptor $\alpha / \delta$ agonists on HDL-cholesterol in vervet monkeys," Journal of Lipid Research, vol. 46, no. 5, pp. 1009-1016, 2005.

[93] R. S. Rosenson, J. D. Otvos, and D. S. Freedman, "Relations of lipoprotein subclass levels and low-density lipoprotein size to progression of coronary artery disease in the pravastatin limitation of atherosclerosis in the coronary arteries (PLACI) trial," American Journal of Cardiology, vol. 90, no. 2, pp. 89-94, 2002.

[94] T. E. Akiyama, G. Lambert, C. J. Nicol et al., "Peroxisome proliferator-activated receptor $\beta / \delta$ regulates very low density lipoprotein production and catabolism in mice on a Western diet," Journal of Biological Chemistry, vol. 279, no. 20, pp. 20874-20881, 2004.

[95] T. Tanaka, J. Yamamoto, S. Iwasaki et al., "Activation of peroxisome proliferator-activated receptor $\delta$ induces fatty acid $\beta$-oxidation in skeletal muscle and attenuates metabolic syndrome," Proceedings of the National Academy of Sciences of the United States of America, vol. 100, no. 26, pp. 1592415929, 2003.

[96] J. Skogsberg, K. Kannisto, T. N. Cassel, A. Hamsten, P. Eriksson, and E. Ehrenborg, "Evidence that peroxisome proliferator-activated receptor delta influences cholesterol metabolism in men," Arteriosclerosis, Thrombosis, and Vascular Biology, vol. 23, no. 4, pp. 637-643, 2003.

[97] I. Gouni-Berthold, E. Giannakidou, M. Faust, H. K. Berthold, and W. Krone, "The peroxisome proliferatoractivated receptor delta $+294 \mathrm{~T} / \mathrm{C}$ polymorphism in relation to lipoprotein metabolism in patients with diabetes mellitus type 2 and in non-diabetic controls," Atherosclerosis, vol. 183, no. 2, pp. 336-341, 2005.

[98] J. Robitaille, D. Gaudet, L. Pérusse, and M.-C. Vohl, "Features of the metabolic syndrome are modulated by an interaction between the peroxisome proliferator-activated receptordelta $-87 \mathrm{~T}>\mathrm{C}$ polymorphism and dietary fat in FrenchCanadians," International Journal of Obesity, vol. 31, no. 3, pp. 411-417, 2007.

[99] N. S. Tan, L. Michalik, B. Desvergne, and W. Wahli, "Peroxisome proliferator-activated receptor- $\beta$ as a target for wound healing drugs," Expert Opinion on Therapeutic Targets, vol. 8, no. 1, pp. 39-48, 2004.

[100] W. R. Oliver Jr., J. L. Shenk, M. R. Snaith et al., "A selective peroxisome proliferator-activated receptor $\delta$ agonist promotes reverse cholesterol transport," Proceedings of the National Academy of Sciences of the United States of America, vol. 98, no. 9, pp. 5306-5311, 2001.

[101] H. Vosper, L. Patel, T. L. Graham et al., "The peroxisome proliferator-activated receptor $\delta$ promotes lipid accumulation in human macrophages," Journal of Biological Chemistry, vol. 276, no. 47, pp. 44258-44265, 2001.

[102] C.-H. Lee, A. Chawla, N. Urbiztondo, D. Liao, W. A. Boisvert, and R. M. Evans, "Transcriptional repression of atherogenic inflammation: modulation by PPAR $\delta$," Science, vol. 302, no. 5644, pp. 453-457, 2003. 
[103] A. C. Li, C. J. Binder, A. Gutierrez et al., "Differential inhibition of macrophage foam-cell formation and atherosclerosis in mice by PPAR $\alpha, \beta / \delta$, and $\gamma$," Journal of Clinical Investigation, vol. 114, no. 11, pp. 1564-1576, 2004.

[104] P. Libby, "Inflammation in atherosclerosis," Nature, vol. 420, no. 6917, pp. 868-874, 2002.

[105] J. S. Welch, M. Ricote, T. E. Akiyama, F. J. Gonzalez, and C. K. Glass, "PPAR $\gamma$ and PPAR $\delta$ negatively regulate specific subsets of lipopolysaccharide and IFN- $\gamma$ target genes in macrophages," Proceedings of the National Academy of Sciences of the United States of America, vol. 100, no. 11, pp. 6712-6717, 2003.

[106] T. L. Graham, C. Mookherjee, K. E. Suckling, C. N. A. Palmer, and L. Patel, "The PPAR $\delta$ agonist GW0742X reduces atherosclerosis in LDLR ${ }^{-/-}$mice," Atherosclerosis, vol. 181, no. 1, pp. 29-37, 2005.

[107] K. R. Reed, O. J. Sansom, A. J. Hayes et al., "PPAR $\delta$ status and Apc-mediated tumourigenesis in the mouse intestine," Oncogene, vol. 23, no. 55, pp. 8992-8996, 2004.

[108] F. S. Harman, C. J. Nicol, H. E. Marin, J. M. Ward, F. J. Gonzalez, and J. M. Peters, "Peroxisome proliferatoractivated receptor- $\delta$ attenuates colon carcinogenesis," Nature Medicine, vol. 10, no. 5, pp. 481-483, 2004.

[109] R. A. Gupta, D. Wang, S. Katkuri, H. Wang, S. K. Dey, and R. N. DuBois, "Activation of nuclear hormone receptor peroxisome proliferator-activated receptor- $\delta$ accelerates intestinal adenoma growth," Nature Medicine, vol. 10, no. 3, pp. 245247, 2004.

[110] B. H. Park, B. Vogelstein, and K. W. Kinzler, "Genetic disruption of PPAR $\delta$ decreases the tumorigenicity of human colon cancer cells," Proceedings of the National Academy of Sciences of the United States of America, vol. 98, no. 5, pp. 2598-2603, 2001.

[111] E. Saez, P. Tontonoz, M. C. Nelson et al., "Activators of the nuclear receptor PPAR $\gamma$ enhance colon polyp formation," Nature Medicine, vol. 4, no. 9, pp. 1058-1061, 1998.

[112] A.-M. Lefebvre, I. Chen, P. Desreumaux et al., "Activation of the peroxisome proliferator-activated receptor $\gamma$ promotes the development of colon tumors in C57BL/6J-APC $\mathrm{Ain}^{\mathrm{i}} /+$ mice," Nature Medicine, vol. 4, no. 9, pp. 1053-1057, 1998. 


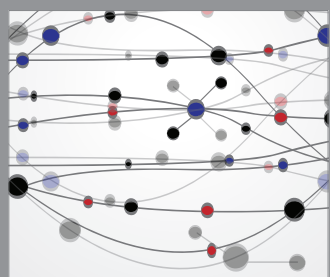

The Scientific World Journal
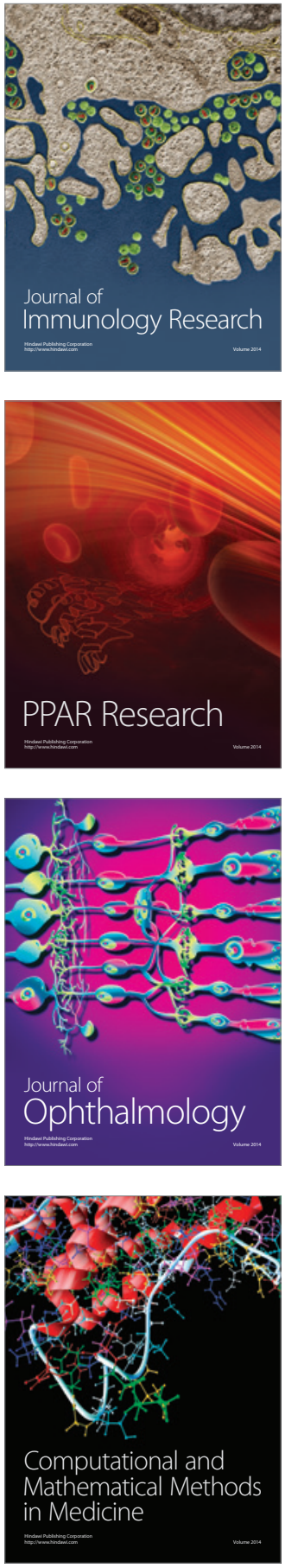

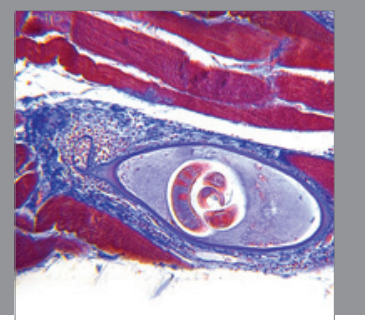

Gastroenterology

Research and Practice
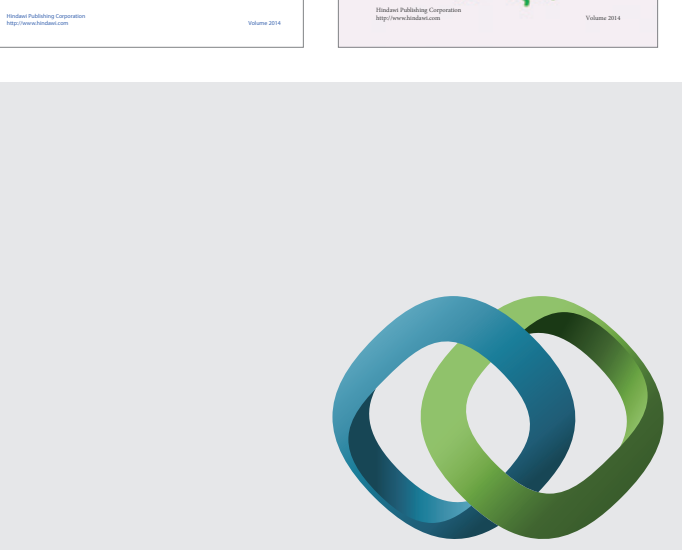

\section{Hindawi}

Submit your manuscripts at

http://www.hindawi.com
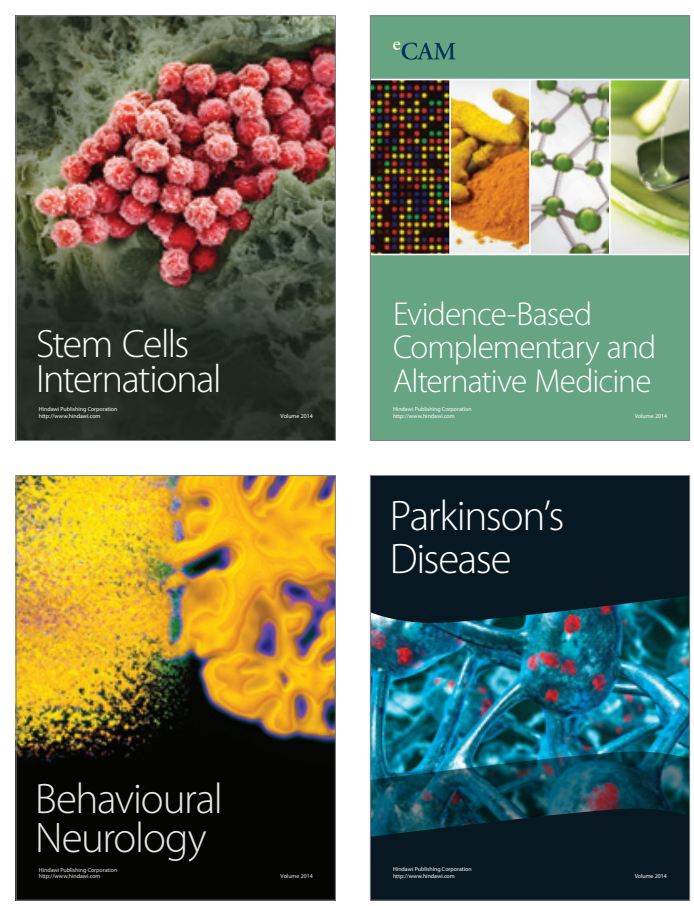

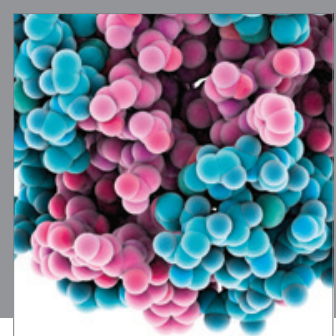

Journal of
Diabetes Research

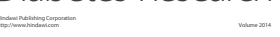

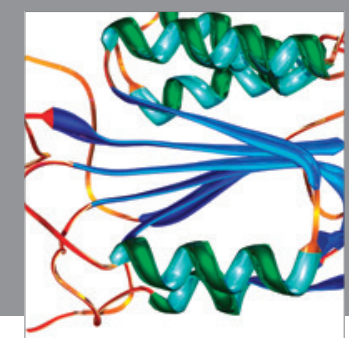

Disease Markers
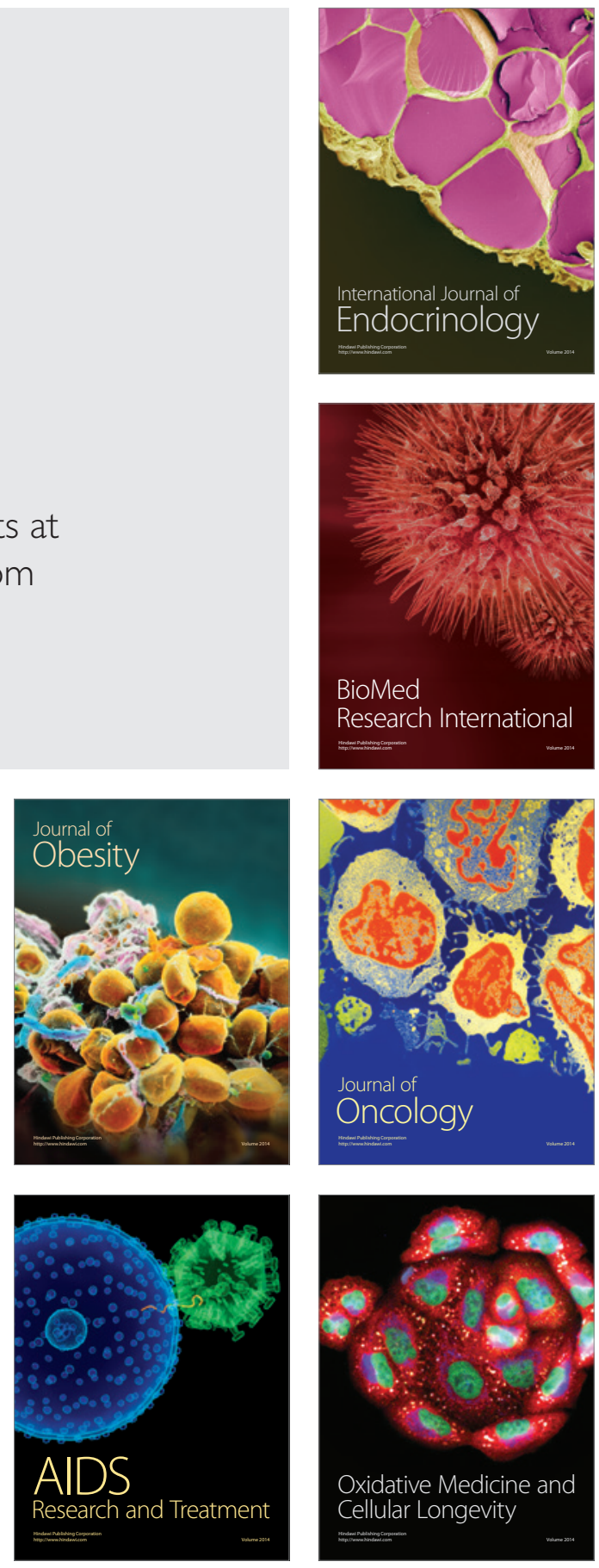